\title{
Population Structure of the Blue Crab Callinectes sapidus in the Maryland Coastal Bays
}

\author{
Kristen A. Lycett \\ Jeffrey D. Shields \\ Virginia Institute of Marine Science \\ J. Sook Chung \\ Joseph S. Pitula
}

Follow this and additional works at: https://scholarworks.wm.edu/vimsarticles

Part of the Aquaculture and Fisheries Commons, and the Marine Biology Commons

\section{Recommended Citation}

Lycett, Kristen A.; Shields, Jeffrey D.; Chung, J. Sook; and Pitula, Joseph S., Population Structure of the Blue Crab Callinectes sapidus in the Maryland Coastal Bays (2020). Journal of Shellfish Research, 39(3), 699-713.

doi: $10.2983 / 035.039 .0316$

This Article is brought to you for free and open access by the Virginia Institute of Marine Science at W\&M ScholarWorks. It has been accepted for inclusion in VIMS Articles by an authorized administrator of W\&M ScholarWorks. For more information, please contact scholarworks@wm.edu. 


\title{
POPULATION STRUCTURE OF THE BLUE CRAB CALLINECTES SAPIDUS IN THE MARYLAND COASTAL BAYS
}

\author{
KRISTEN A. LYCETT, ${ }^{1,2}$ JEFFREY D. SHIELDS, ${ }^{3}$ J. SOOK CHUNG ${ }^{4}$ AND \\ JOSEPH S. PITULA ${ }^{1}$ * \\ ${ }^{1}$ University of Maryland Eastern Shore, 1 Backbone Rd., 2107 Carver Hall, Princess Anne, MD 21853; \\ ${ }^{2}$ Salisbury University, 1101 Camden Ave., Salisbury, MD 21801; ${ }^{3}$ Virginia Institute of Marine Science, \\ The College of William \& Mary, Gloucester Point, VA 23062; ${ }^{4}$ Institute of Marine and Environmental \\ Technology, University of Maryland Center for Environmental Science, Baltimore, MD 21202
}

\begin{abstract}
The population structure of the blue crab Callinectes sapidus was examined in the Maryland Coastal Bays (MCB) from 2014 to 2016. Crabs were sampled from April to December of each year. Size-frequency distributions showed a strong seasonal cycle, with small crabs being abundant in April, increasing in size through September, with adult crabs observed in the highest proportions from August through October of each year. A subsample of crabs was assayed for hemolymph ecdysone concentrations to examine molting patterns in field-collected blue crabs. Molting was observed throughout the sampling season, peaking in April for immature crabs, with lows in all size classes occurring in October. The mean size at maturity $\left(L_{50}\right)$ for females collected in this study was $116 \mathrm{~mm}$ carapace width $(\mathrm{CW})$, which is comparable to that reported for the lower Chesapeake Bay $(\mathrm{CB})$ and suggests crabs in the $\mathrm{MCB}$ are not significantly smaller as previously thought; however, large crabs (>127 $\mathrm{mm} \mathrm{CW})$ appear to make up a smaller proportion of the total population in the MCB than in CB. Ovigerous females were observed at two distinct locations depending on the season, with 13/15 (86.7\%) in southern Chincoteague Bay in April and May and 24/41 (58.5\%) nearest to the Ocean City Inlet in July and August, indicating two potentially distinct spawning grounds and periods. This work suggests that blue crab reproductive success and general population trends are similar across both systems, with fishing pressure or disease in the MCB potentially explaining the low abundance of adult male crabs.
\end{abstract}

KEY WORDS: population structure, Callinectes sapidus, crustacean ecology, molting, size-frequency distribution

\section{INTRODUCTION}

Shellfish populations are a major economic resource in the United States, with shellfish making up approximately $57 \%$ of all commercial fishery landings in 2016 (NOAA 2018). Because of their benthic lifestyles, complex life histories, and discontinuous growth, shellfish species often require different management strategies and additional stock assessment data as compared with finfish (Caddy 1989, Smith \& Addison 2003). For example, finfish are able to grow continuously, whereas crustaceans grow discontinuously by molting, or shedding their old cuticular exoskeleton, and replacing it with the cuticle of the new instar. The shedding of the exoskeleton makes it difficult to perform tagging studies or age crustacean species accurately because environmental and physiological factors can affect molting and growth. This, coupled with variability in growth due to environmental conditions, makes understanding the age structure of crustacean populations complicated.

In the blue crab Callinectes sapidus Rathbun, molting frequency depends on a variety of factors, including life-history stage, size class, nutrition, and temperature (Smith \& Chang 2007). Because its geographical distribution is extensive, ranging from Nova Scotia to Argentina (Williams 1984), patterns in the life history of the blue crab may vary by region or even habitat. For example, phenological variations in latitude or ecosystem can create a disparity between populations. In the mid-Atlantic region, blue crabs are known to hibernate, or overwinter, during periods of low temperature, but overwintering does not occur in subtropical or tropical regions (Churchill 1919, Van Engel 1958, Havens \& McConaugha 1990,

*Corresponding author. E-mail: jspitula@umes.edu DOI: $10.2983 / 035.039 .0316$
Smith \& Chang 2007). Moreover, crabs in temperate regions such as Chesapeake Bay (CB) cease molting, and hence growth, from late November through early April each year; however, this does not occur in populations found in warmer regions such as the Gulf of Mexico (Van Engel 1958, Tagatz 1968).

Because CB is home to a large population of blue crabs and is a major fishery, research traditionally has focused on its blue crab population. Due east of $\mathrm{CB}$, on the opposite side of the Delmarva Peninsula, resides a much smaller bay system collectively known as the Maryland Coastal Bays (MCB). The $\mathrm{MCB}$ are composed of several partially connected subestuaries, including Assawoman Bay, St. Martin River, Sinepuxent Bay, Newport Bay, and a portion of Chincoteague Bay. These bays represent a small, shallow, high salinity, coastal estuarine system enclosed by barrier islands to the east, including Assateague Island and Ocean City, MD (Fig. 1). The MCB system maintains a population of blue crabs that supports both recreational and commercial fisheries that are distinctly separate from those in CB. Many similarities are thought to exist between these two populations in terms of ecology, but little research has been carried out to explore this.

The goal of this work was to explore the population dynamics of blue crabs in the MCB and compare, where possible, with the demography of the blue crab population in CB. Despite being at an identical latitude, the MCB tend to be warmer than the larger CB system because of quicker heating of its shallow lagoons and bays during spring and summer. In addition, freshwater inputs are not as extensive in the $\mathrm{MCB}$, thereby generating a system of higher and more uniform salinity than in $\mathrm{CB}$. Thus, it was expected that there would be some variation between the blue crab populations in these two systems. 


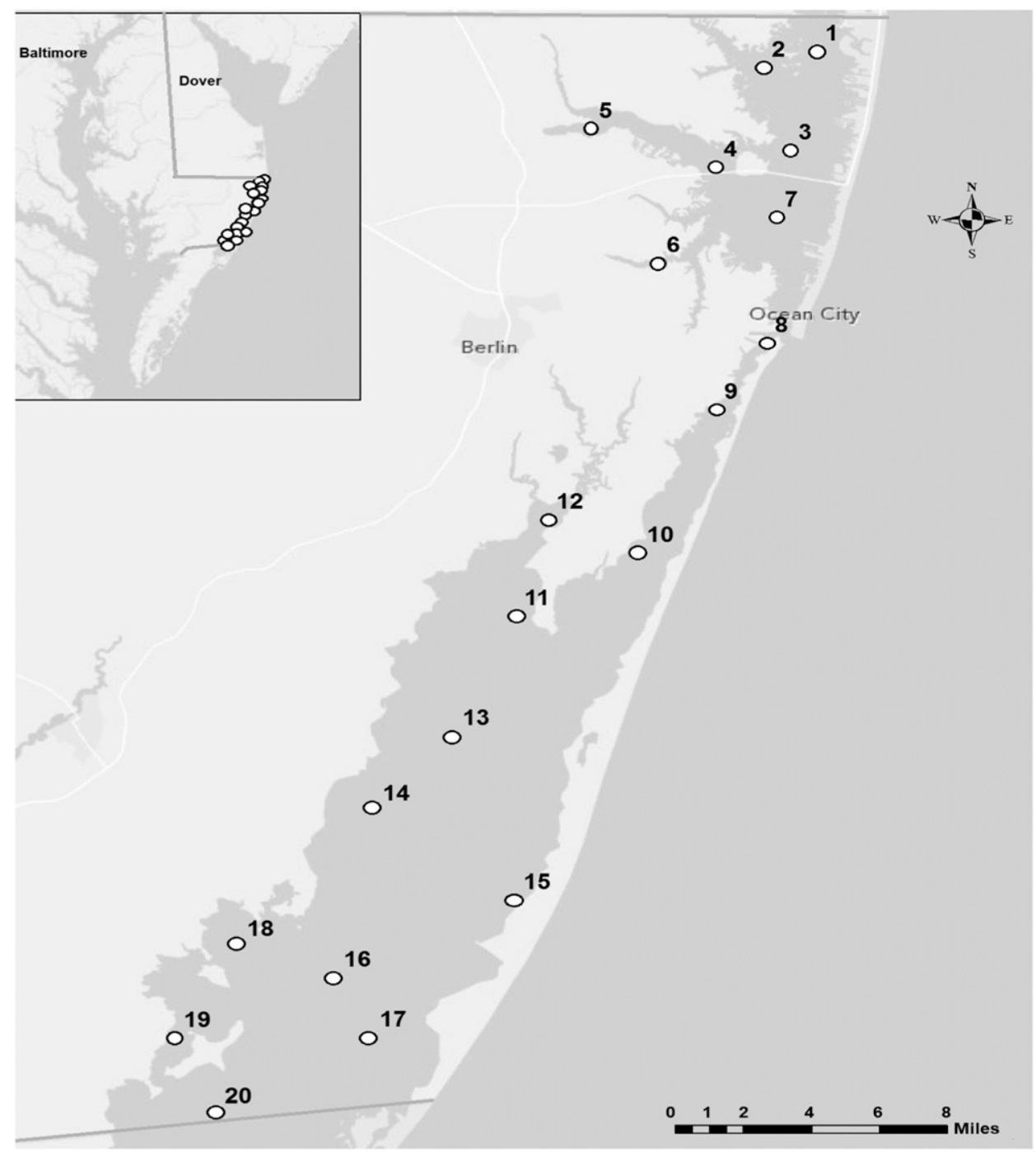

Figure 1. Map of sampling sites. Sites 1-3 = Assawoman Bay; Sites 4-5 = St. Martin River; Sites 6-7 = Isle of Wight; Sites 8-10= Sinepuxent Bay; Sites 11-12 = Newport Bay; Sites 13-20 = Chincoteague Bay. Base map $\odot$ Esri, DeLorme, NAVTEQ.

\section{MATERIALS AND METHODS}

\section{Sample Collection}

The Maryland Department of Natural Resources performs trawl surveys as part of their ongoing Coastal Bays Fisheries Investigation Program in the MCB. These surveys are performed monthly, April-October, at 20 sites throughout the system (Fig. 1) and were designed to provide baseline data on the abundance of juveniles and adults of commercially and recreationally important species, including blue crabs and many other species. The data presented here were collected in conjunction with these surveys from 2014 to 2016.

Trawling was performed with a 16-ft. semi-balloon trawl towed at 6 knots for $3 \mathrm{~min}$. A full description of the sampling gear and method are described on the Maryland Department of Natural Resources website under "Coastal Bays Fisheries Investigation" (Maryland Department of Natural Resources Coastal Bays Fisheries Investigation). At each site, environmental data were collected before the trawl was performed. A
Pro1020 YSI was used to collect water temperature, salinity, and dissolved oxygen at the surface and at the bottom. Average salinities reported here use the bottom salinity reading of a given site or sub-estuary across all data points collected during the course of this study.

In each trawl, finfish species were counted and measured, blue crabs were counted, and the total volume of all algae was measured in a marked container, with the percentage volume of each algal species being estimated. In addition, other invertebrate species were counted or their abundances estimated using marked containers, including additional species of crabs, shrimp, ctenophores, and jellyfish.

A total of 50 blue crabs were further sampled in each trawl, with the remaining blue crabs only being counted. Recorded data included the carapace width (the distance between the tips of the epibranchial spines; $\mathrm{CW}$ ) and sex of each crab. The maturity status of each female crab was noted as immature or mature, based on the shape of the abdominal tergites (the "apron") on the abdomen of the crab. In addition, mature female crabs that were egg-bearing (ovigerous, eggers, or sponge 
crabs) were recorded, but the developmental stage of the eggs (based on color) was not recorded because of their rapid development time (<14 days). Male crabs did not have maturity status recorded in the field, but maturity based on size is described in the following text. For the female crabs collected in this study, six crabs did not have their maturity status recorded and were therefore not included in analyses involving maturity status or ovigerous crabs.

Crabs less than $10 \mathrm{~mm} \mathrm{CW}$ showed inconsistencies in sampling, indicating that they may not have been well sampled by the trawl gear used in this study. This suggests that gear selectivity was low for crabs less than $10 \mathrm{~mm} \mathrm{CW}$.

\section{Crab Age Categories}

To track growth, a total of four size categories were used. Measured crabs were grouped by size into recruits, juveniles, subadults, and adults to explore population structure (see in the following text). Blue crab larvae take approximately 3-4 wk to develop from hatching through all seven or eight zoeal stages, and 1-2 wk to develop through the megalopal stage, depending on environmental conditions (Churchill 1942, Sandoz \& Rogers 1944, Costlow \& Bookhout 1959, Brumbaugh \& McConaugha 1995, Zmora et al. 2005). It then takes approximately 1-2 mo after recruitment for a crab to grow to approximately $20 \mathrm{~mm} \mathrm{CW}$ $\left(C_{6}\right.$, or the sixth instar; Pile et al. 1996, Zmora et al. 2005, Cunningham \& Darnell 2015). Thus, in the present study, crabs less than or equal to $20 \mathrm{~mm} \mathrm{CW}$ were considered to have less than 3 mo of active growing time and are here termed "recruits"; those from 21 to $60 \mathrm{~mm} \mathrm{CW}$ were considered "juveniles," those from 61 to $106 \mathrm{~mm} \mathrm{CW}$ were "subadults," and those more than $107 \mathrm{~mm}$ CW were considered adults. This size is based on the observation that $50 \%$ of males collected in lower CB were sexually mature at $107 \mathrm{~mm} \mathrm{CW}$ (Van Engel 1990), and the mean size at maturity of female blue crabs in lower tributaries of $\mathrm{CB}$ was estimated to be 107.9 mm CW from 1992 to 2000 (Lipcius \& Stockhausen 2002). Therefore, $107 \mathrm{~mm} \mathrm{CW}$ was selected as the lower limit for the "adult" size class for ease of grouping. In cases where sexual maturity is being discussed, as indicated by apron shape, females are referred to as "mature" rather than the size category "adults." In addition, the actual $L_{50}$ for the female crabs collected in this study was calculated as described in the following text.

\section{Radioimmunoassay (RIA) Assessment of Molt Stage}

A subsample of crabs was collected for analysis with an ecdysteroid RIA to more accurately determine their molt stages as described by Chung (2010). These crabs were randomly selected during field sampling, placed into bags labeled with the date and site, and stored on ice until sampling was completed. Hemolymph was drawn the same day that sampling occurred at the University of Maryland Eastern Shore, Paul S. Sarbanes Coastal Ecology Center. Aliquots of $100 \mu \mathrm{L}$ of hemolymph were taken from each crab using a $1-\mathrm{mL}$ syringe equipped with a 27-ga needle. Hemolymph was immediately mixed in a 1:1 ratio with an anticlotting buffer (HEPES $10 \mathrm{mM}, \mathrm{NaCl} 400 \mathrm{mM}, \mathrm{KCl}$ $10 \mathrm{mM}$, glucose $100 \mathrm{mM}$, NaHCO3 $10 \mathrm{mM}$, and EDTA $10 \mathrm{mM}$; pH 7.4; modified from Söderhäll \& Smith 1983) and chilled on ice. Hemolymph was frozen at $-20^{\circ} \mathrm{C}$ for use at a later date.

The RIA is described in Lycett et al. (2018). In brief, hemolymph samples were run in duplicate with standards run in triplicate, with the bound form counted using a beta counter (Perkin Elmer). The resulting data were analyzed using the AssayZap program (Biosoft). Animals were categorized as either in the inter-molt stage or in premolt (preparatory to molting) stages $\left(D_{0}-D_{4}\right.$ in the molt cycle). In this work, "intermolt" crabs were considered to be those not preparing to molt, as indicated by low ecdysone levels, including crabs in postmolt (ecdysone concentration less than $10 \mathrm{ng} / \mathrm{mL}$ ) and intermolt stages (ecdysone concentrations 10-30 ng/m; Soumoff \& Skinner 1983, Chung 2010; Techa \& Chung 2013). Crabs in the "active" stage were those that had elevated ecdysone levels ( $>30 \mathrm{ng} / \mathrm{mL}$ ) and would be proceeding through ecdysis in the near future. Crabs were further categorized as mature males $(\geq 107 \mathrm{~mm} \mathrm{CW})$ and all immature crabs $(<107 \mathrm{~mm} \mathrm{CW})$. Sexually mature female crabs were not included in the molting data because, with a few rare exceptions, they have a terminal molt and therefore would not be in the active molt cycle. Instead, they are permanently in the inter-molt stage.

\section{Statistical Analysis}

Statistical analysis was performed in $\mathrm{R}$ (version 3.6.1; R Core Team 2019) using $\mathrm{R}$ studio (version 1.2.1335; R Studio Team 2018). All tests were considered significant at $P<0.05$. The mean size at maturity $\left(L_{50}\right)$ was calculated using the $\mathrm{R}$ package "sizeMat," which uses a logistic approach (TorrejonMagallanes 2020). A one-way analysis of variance was used to explore variation across sites. In cases where data were significantly non-normal, as determined by a Shapiro-Wilk Test, data were $\log 10$ transformed (McDonald 2014). A Tukey HSD test was used as a post hoc analysis to confirm the results of the ANOVA. The chi-square goodness of fit test was used on frequency data to determine if sex ratios were significantly skewed. For this test, a ratio of 1:1 was used as the expected relationship. A $G$-test for goodness of fit was used to determine if sex ratios were significantly different between years. Linear regression was used to explore the relationship between the density of ovigerous crabs and salinity at individual sites, and the relationship between the density of mature female crabs and salinity at individual sites.

\section{RESULTS}

Over the $3 \mathrm{y}$ of the study, total catch varied but gear and sampling method did not, indicating that the change in catch represented fluctuations in the blue crab population in the MCB. In 2014, 3,140 crabs were caught, compared with 4,917 crabs in 2015 and 6,039 crabs in 2016. The highest monthly catch was seen in June of all 3 y (987 crabs in 2014, 1,889 crabs in 2015, and 1,706 crabs in 2016). The lowest monthly catch was seen in October of all 3 y (162 crabs in 2014, 120 crabs in 2015, and 197 crabs in 2016). Of the crabs caught, 2,037 were measured and sexed in 2014, compared with 2,683 in 2015 and 2,962 in 2016. These numbers represent $64.9 \%$ of the total catch in $2014,54.6 \%$ of the catch in 2015, and $49.0 \%$ of the catch in 2016 (see Materials and Methods). The gender of early benthic juveniles could not be identified less than approximately $10 \mathrm{~mm}$, resulting in slight discrepancies between the number sexed and the number measured.

Crab size varied by season, with juvenile crabs dominating the catches early in the sampling season (Fig. 2, Table 1, Appendix Figure 1). Similar trends in the relative abundance of 

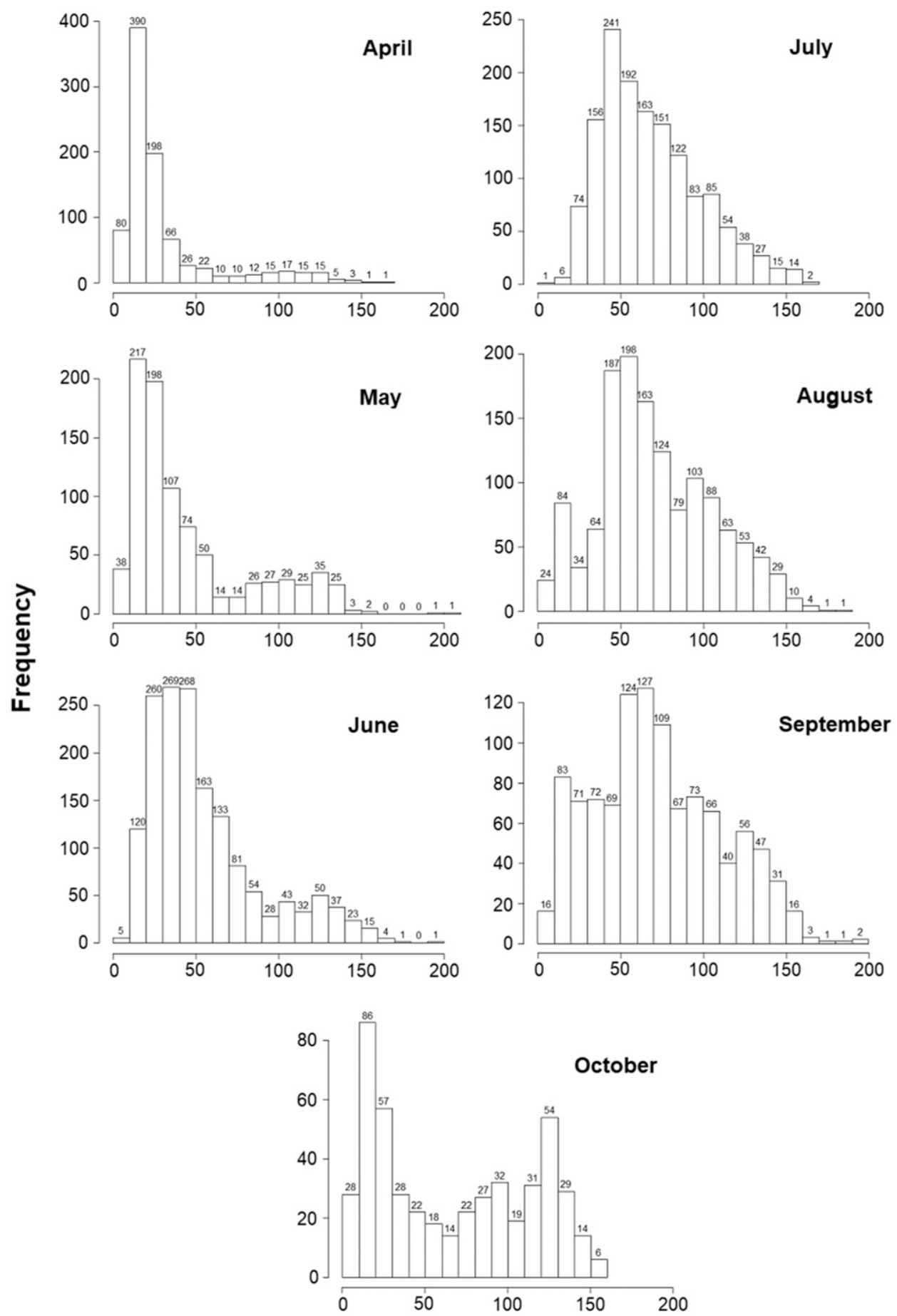

\section{Carapace Width $(\mathrm{mm})$}

Figure 2. Size frequency histograms of blue crab carapace width by month for all 3 y pooled. Values above each bin represent the total number of crabs in that bin.

different size classes were observed each year from April through August, with smaller crabs dominating early in the year, larger crabs in the summer, and then a more even distribution of crabs in September and October. This trend is further elucidated when crabs from all 3 y are pooled and grouped by size class (Table 1). Adult crabs ( $\geq 107 \mathrm{~mm} \mathrm{CW}$ ) made up $30.0 \%$
(146/487 crabs) of the sampled population in October, a higher proportion than was seen in any other month, but their highest absolute abundance was in August when 232 total adults were captured. The lowest absolute abundance and relative proportion of adult crabs was seen in April at 5.1\% (45/886 crabs). During the April sampling, most sites had relatively low catch 
TABLE 1.

Size frequencies and relative abundance of each size category for different crab sizes by month for 2014-2016.

\begin{tabular}{|c|c|c|c|c|c|c|c|}
\hline Size & April, $n(\%)$ & May, $n(\%)$ & June, $n(\%)$ & July, $n(\%)$ & August, $n(\%)$ & September, $n(\%)$ & October, $n(\%)$ \\
\hline Recruits & $416(47.0)$ & $224(25.3)$ & $91(5.7)$ & $4(0.3)$ & $99(7.3)$ & 85 (7.9) & $98(20.1)$ \\
\hline Juveniles & $361(40.7)$ & $452(51.0)$ & $981(61.8)$ & $625(43.9)$ & $450(33.3)$ & $326(30.4)$ & $137(28.1)$ \\
\hline Subadults & $62(7.0)$ & $106(12.0)$ & $335(21.1)$ & $605(42.5)$ & $570(42.2)$ & $437(40.7)$ & $106(21.8)$ \\
\hline Adults & $47(5.3)$ & 104 (11.7) & $180(11.3)$ & $190(13.3)$ & $232(17.2)$ & $226(21.0)$ & $146(30.0)$ \\
\hline Total & 886 & 886 & 1,587 & 1,424 & 1,351 & 1,074 & 487 \\
\hline
\end{tabular}

per unit effort, but a few sites had very large catch per unit effort, suggesting that crabs were segregating by habitat or site in some areas and in some years.

Recruits $(<20 \mathrm{~mm} \mathrm{CW})$ were abundant early in the year, with the highest proportions seen in April at 47\% (416/886 crabs) and May $25.3 \%$ (224/886 crabs). The relative proportion of recruits decreased in June and July, remained low in August and September, but increased in October to $20.1 \%$ (98/487 crabs). Larger juveniles (20-60 $\mathrm{mm} \mathrm{CW}$ ) had high relative abundance in May and June at 51\% (451/886 crabs) and 61.8\% (981/1,587 crabs), respectively, and subadults had high relative abundances from July through September. The smallest juveniles (less than $4 \mathrm{~mm} \mathrm{CW}$ ) are absent from this dataset as these crabs are too small to be sampled appropriately using the trawl net described here. In addition, the relatively small numbers of crabs less than $6 \mathrm{~mm} \mathrm{CW}$ (3 crabs were $4 \mathrm{~mm} \mathrm{CW}$ and eight crabs were $5 \mathrm{~mm}$ $\mathrm{CW}$ in all $3 \mathrm{y}$ of sampling) suggest that this size class is not well sampled. Thus, this dataset underestimates the number of recently settled juvenile crabs and instead shows patterns for larger juveniles $\left(\mathrm{C}_{6}\right.$ instars and above).

Ecdysone concentrations in hemolymph samples were used to determine the molt stages for crabs in a subsample of daily trawl collections (116 crabs in 2014, 121 crabs in 2015, and 251 crabs in 2016). This subsample of crabs did not include recruits because of a minimum volume of hemolymph needed for the assay. Sampled crabs ranged in size from 27 to $157 \mathrm{~mm} \mathrm{CW}$, with an average size of $75.3 \mathrm{~mm} \mathrm{CW}$. When crabs from all years are pooled (all immature crabs and adult males), there appears to be two peaks in molting activity, April-May and JulySeptember (Table 2). Juvenile crabs were actively molting throughout the year, as more than $50 \%$ of crabs had elevated ecdysone in every month with the exception of October. In April, every juvenile crab tested was in a premolt stage (19/19 crabs), compared with a low of $45.5 \%$ (5/11 crabs) in October. In the subadult size class, the highest percentage of crabs in premolt was observed in June at 95\% (19/20 crabs) and the lowest percentage in October at 15\% (3/20 crabs). Adult male crabs appeared to have lower molting activity throughout the year, with a peak in July at $66.7 \%$ (2/3 crabs) and lows in June and October. In June, no crabs ( $0 / 6$ crabs) were actively molting, and in October, $14.3 \%$ (2/14 crabs) of crabs were actively molting.

There were significantly more male crabs than female crabs in all $3 \mathrm{y}$ of the study $\left(2014 X^{2}=4.1, \mathrm{df}=1, P<0.05 ; 2015 X^{2}=\right.$ $53.3, \mathrm{df}=1, P<0.001,2016 X^{2}=9.1, \mathrm{df}=1, P<0.01$; Appendix Table 1). The years 2014 and 2016 were not significantly different from each other (G-test, $P=0.71$ ), but 2015 had significantly more males caught than both 2014 and 2016 ( $G$-test, $P<$ 0.01 for both tests). This variation between years appears to be influenced primarily by the month of May, as there was no significant difference between the number of males and females in May 2014 and May 2016, although there were significantly more males in May $2015\left(X^{2}=12.26, P<0.001 ; P=0.57\right.$; and $P=0.12$, respectively; Appendix Table 1). The August samples also added to the variability, as there was no significant difference between the number of males and females in $2014\left(X^{2}=\right.$ $19.81 ; P=0.43)$, but there were significantly more males in 2015 $(P<0.01)$ and significantly more females in $2016\left(X^{2}=7.1, P<\right.$ $0.01)$. The other months had the same trend in all $3 \mathrm{y}$. For this reason, data were grouped to explore general trends in sex ratios

TABLE 2.

Molt stage (\%) by size class by month for 2014-2016 based on ecdysone levels.

\begin{tabular}{|c|c|c|c|c|c|c|c|}
\hline & April & May & June & July & August & September & October \\
\hline All crabs $(n)$ & 49 & 29 & 56 & 49 & 132 & 116 & 45 \\
\hline Active, $\%$ & 79.6 & 75.9 & 42.9 & 65.3 & 72.7 & 73.3 & 20.0 \\
\hline Inter-molt, $\%$ & 20.4 & 24.1 & 57.1 & 21.6 & 27.3 & 26.7 & 80.0 \\
\hline Juveniles (n) & 19 & 17 & 16 & 17 & 51 & 32 & 11 \\
\hline Active, $\%$ & 100.0 & 82.4 & 62.5 & 58.8 & 76.5 & 84.4 & 45.5 \\
\hline Inter-molt, \% & 0.0 & 17.6 & 37.5 & 41.2 & 23.5 & 15.6 & 54.5 \\
\hline Subadults $(n)$ & 20 & 5 & 36 & 30 & 70 & 74 & 20 \\
\hline Active, $\%$ & 95.0 & 80.0 & 44.4 & 73.3 & 74.3 & 70.3 & 15.0 \\
\hline Inter-molt, $\%$ & 5.0 & 20.0 & 55.6 & 26.7 & 25.79 & 29.7 & 85.0 \\
\hline Adult males $(n)$ & 11 & 6 & 6 & 3 & 10 & 8 & 14 \\
\hline Active, $\%$ & 36.4 & 50.0 & 0.0 & 66.7 & 30.0 & 50.0 & 14.3 \\
\hline Inter-molt, $\%$ & 63.6 & 50.0 & 100.0 & 33.3 & 70.0 & 50.0 & 85.7 \\
\hline
\end{tabular}


by month (Table 3 ). Sex ratios were not significantly different from June through August; however, there were significantly more male crabs than female crabs collected from April to May and September to October (Table 3). In addition, sex ratios of sexually mature females and adult males showed significantly more male crabs in May, July, and October (Appendix Table 1).

Of the female crabs caught in the course of this study, sexually mature females made up only $11.6 \%$ of the sample (409/ 3,514 ; Table 4). These sexually mature females had an average size of $133.6 \mathrm{~mm} \mathrm{CW}$, with the smallest measuring $60 \mathrm{~mm} \mathrm{CW}$ and the largest measuring $177 \mathrm{~mm} \mathrm{CW}$. Although there was some variation in the average size of sexually mature females by sub-estuary (Appendix Table 2), the mean size was not significantly different (Tukey HSD, $P>0.05$ ); however, there was significant variation in the presence of mature females (as a proportion of the total number of females collected) across different sub-estuaries $\left(F_{(5,358)}=10.9, P<0.001\right)$, with Sinepuxent Bay having a higher proportion of mature females than all other sub-estuaries.

The relationship between the total number of mature females collected at a given site and average salinity at that site was weak $\left(R^{2}=0.12\right)$, but salinity is highly variable (Appendix Table 3 ), depending on a variety of factors, including recent rainfall, tide stage, and wind conditions at the time the salinity was recorded. Regardless, salinity was significantly different $\left(F_{(5,383)}=14.233, P<0.001\right)$ across the six sub-estuaries. The lowest average salinity by sub-estuary was $24.6 \mathrm{ppt}$ for St. Martin River (Appendix Table 2), which includes sites T004 and T005 (Fig. 1). The highest average salinity by sub-estuary was $29.1 \mathrm{ppt}$ for Sinepuxent Bay, which includes sites T008, T009, and T010.

The mean size at maturity $\left(L_{50}\right)$ for female crabs collected in this study was calculated as $116 \mathrm{~mm} \mathrm{CW}$ (Fig. 3) using both Frequentist regression $\left(L_{50}=116.3, R^{2} 0.86, \mathrm{CI}=114.9-117.5\right)$ and Bayesian regression $\left(L_{50}=116.2, R^{2} 0.86\right.$, CI $=$ 114.8-117.6). Because crabs are measured in whole millimeters and both methods of calculation round to $116 \mathrm{~mm}$, this is the size presented here.

Of the 409 sexually mature crabs collected, 95 were eggbearing females (ovigerous crabs), with an average size of $133.6 \mathrm{~mm} \mathrm{CW}$. The smallest ovigerous female recorded was $70 \mathrm{~mm} \mathrm{CW}$, and the largest female recorded was $172 \mathrm{~mm} \mathrm{CW}$. In April, relatively few ovigerous crabs were seen, but they made up a high proportion of the sexually mature females that

TABLE 3.

Sex ratios of blue crabs by month pooled for 2014-2016.

\begin{tabular}{lrcccc}
\hline \hline Month & \multicolumn{1}{c}{$\boldsymbol{N}$} & \% Female & \% Male & $\boldsymbol{X}^{\mathbf{2}}$ & $\boldsymbol{P}$ value \\
\hline April & 879 & 40.6 & 59.4 & 31.0 & $2.6 \times 10^{-8}$ \\
May & 885 & 45.9 & 54.1 & 6.0 & $1.4 \times 10^{-2}$ \\
June & 1,587 & 48.6 & 51.4 & 1.2 & 0.3 \\
July & 1,424 & 49.2 & 50.8 & 0.3 & 0.6 \\
August & 1,349 & 49.1 & 50.9 & 0.4 & 0.5 \\
September & 1,072 & 40.6 & 59.3 & 37.3 & $1.0 \times 10^{-9}$ \\
October & 478 & 38.7 & 61.3 & 24.4 & $7.8 \times 10^{-7}$ \\
Total & 7,675 & 45.9 & 54.1 & 52.4 & $4.6 \times 10^{-13}$ \\
\hline
\end{tabular}

Significant $P$ values are highlighted in gray. Sex ratios by year and for only mature crabs are available in Appendix Table 1.
TABLE 4.

Maturity and reproductive status of female blue crabs by month pooled for 2014-2016.

\begin{tabular}{lcccc}
\hline \hline Month & Immature & Mature & Ovigerous & \% Ovigerous \\
\hline April & 348 & 9 & 6 & 66.7 \\
May & 379 & 27 & 9 & 33.3 \\
June & 684 & 83 & 36 & 43.4 \\
July & 640 & 61 & 24 & 39.3 \\
August & 569 & 93 & 17 & 18.3 \\
September & 345 & 91 & 3 & 3.3 \\
October & 140 & 45 & 0 & 0 \\
Total & 3,105 & 409 & 95 & 23.2 \\
\hline
\end{tabular}

were caught (Table 4). Ovigerous crabs were most frequent in summer months, with 36 crabs caught in June across all 3 y, 24 crabs in July, and 17 crabs in August (Appendix Table 4). By year, the abundance of ovigerous crabs varied, with most of the ovigerous crabs being caught in July 2014 and 2015 and June 2016. The observed abundance of ovigerous crabs in 2014 and 2015 was relatively low, with 19 and 13 crabs caught over the sampling season, respectively. More ovigerous crabs (63) were caught in 2016.

The presence of ovigerous crabs was highly variable. All ovigerous crabs caught in April and the majority (6/9) caught in May were from Chincoteague Bay (Appendix Table 2). In June, ovigerous crabs were caught in many different sites, but the majority (22/36 crabs) were seen in Sinepuxent Bay (sites T009 and T010), south of the Ocean City Inlet. In July, the majority (15/24 crabs) were seen in Assawoman Bay (sites T003 and T007), north of the Ocean City Inlet. Throughout the year, most ovigerous crabs were caught at sites T003 (19 crabs), T007 (17 crabs), and T009 (19 crabs). Ovigerous crabs were seen at site T003 in Assawoman Bay from May through September, whereas they were only seen June through August at sites T007 (Assawoman Bay) and T009 (Sinepuxent Bay). Although

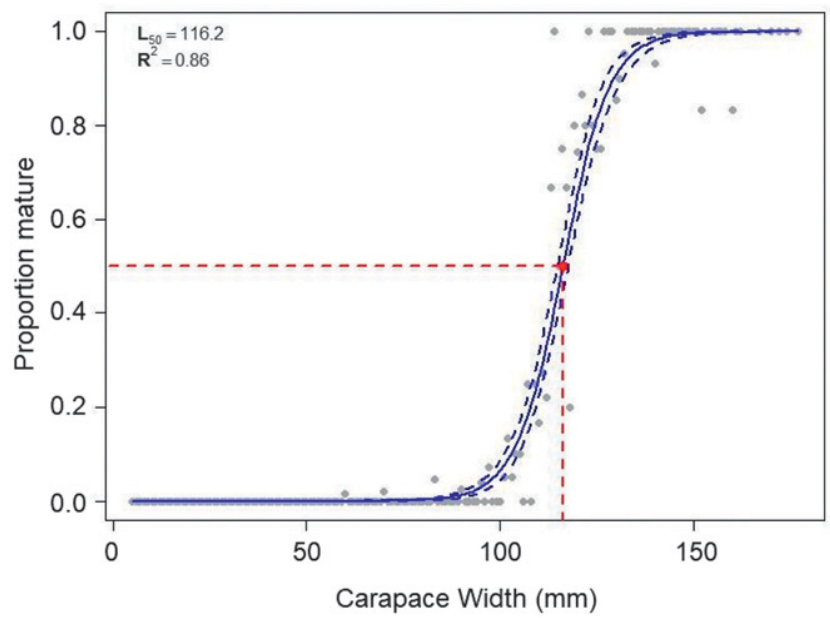

Figure 3. Logistic curve fitted to the physiological sexual maturity of Callinectes sapidus females sampled from 2014 to 2016 in the Maryland and Virginia Coastal bays. The horizontal line represents the proportion of $\mathbf{5 0} \%$ sexually mature. $\mathrm{L}_{\mathbf{5 0}}$, size at $\mathbf{5 0} \%$ sexual maturity. 
salinity levels tended to be higher at these sites, the relationship between high salinity and the abundance of ovigerous crabs was weak $\left(R^{2}=0.28\right)$, likely because salinity was relatively high throughout the system.

\section{DISCUSSION}

Historically, blue crabs from the MCB were thought to be smaller, on average, than those maturing in CB (Porter 1955, Porter 1956, Lipcius et al. 2003, Hall et al. 2004, Hines 2007). This is potentially due to the influence of higher salinity in the MCB, causing a lower molt increment during molting; some researchers have also observed a longer molt duration (less frequent molting) and a greater size increase (molt increment) in crabs held in lower salinity than in high salinity (de Fur et al. 1988). Fisher (1999) also observed smaller sizes at maturity for female crabs in higher salinity waters, suggesting smaller changes in size across each molt, compared with females in lower salinity waters; however, other researchers have reported little to no influence of salinity on molting and growth (Haefner \& Shuster 1964, Neufeld \& Cameron 1994, Cunningham \& Darnell 2015).

Based on the crabs collected in this study, it does not appear that crabs from MCB are significantly smaller than those from Chesapeake. Because of seasonal variation, it is not useful to compare the average size of all crabs, rather the mean size of sexually mature females can serve as a proxy to examine the influence of environmental factors on size (Fisher 1999). The $L_{50}$ reported here $(116 \mathrm{~mm} \mathrm{CW})$ is similar to that reported for the lower CB (118.4 mm CW from 1988 to 1991 and $107.9 \mathrm{~mm}$ CW from 1994 to 1996; Lipcius \& Stockhausen 2002). In addition, the average size of sexually mature females collected in this study (133.6 mm CW) is similar to that reported by Lipcius and Stockhausen (2002) for lower CB (no salinity data provided), which was $132.5 \mathrm{~mm}$ CW for crabs collected from 1994 to 2002; however, Lipcius and Stockhausen (2002) did observe that the average size of sexually mature females in lower CB was smaller than that of those in the bay's tributaries, where the average size was $139.7 \mathrm{~mm} \mathrm{CW}$ from 1994 to 1997. In this context, it should be noted that the migration history of the crabs in lower CB can vary significantly over distance and salinity regimes. This potentially confounds the comparison; nevertheless, crabs from the tributaries with lower salinities are typically larger than those from the main stem of $\mathrm{CB}$, lending some support to the notion that crabs maturing in low salinity waters are typically larger than those maturing in high salinity waters. Future work should continue to examine average sizes and distributions of sexually mature females, especially now that fishing pressure on female crabs has been reduced in $\mathrm{CB}$; this may affect size at maturity, and therefore the average size of sexually mature females (Lipcius \& Stockhausen 2002, Miller et al. 2011).

Notably, large crabs can be found in MCB, although they may not be as common as in CB. Approximately $1.5 \%$ of all crabs collected in this study were above $150 \mathrm{~mm} \mathrm{CW}$ (113 crabs of 7,695 total crabs), with the largest crab measuring $210 \mathrm{~mm}$ $\mathrm{CW}$; thus, crabs in MCB are capable of growing to comparable sizes as those in $\mathrm{CB}$. Nonetheless, large crabs appear to make up a relatively small proportion of the population in $\mathrm{MCB}$ throughout most of the year. This is in contrast to observations in CB where Hines et al. (1987) observed April peaks at 30 and
$100 \mathrm{~mm} \mathrm{CW}$ in the Rhode River. In this study, only the smaller peak of crabs at 20-40 mm CW was observed (Fig. 2, Appendix Figure 1). In fact, adult crabs ( $\geq 107 \mathrm{~mm} \mathrm{CW}$ ) made up only $14.6 \%$ of all crabs sampled $(1,125$ crabs of 7,695 total crabs measured) throughout this study. Again, there are little data on specific sizes to compare with crabs in $\mathrm{CB}$, but the $\mathrm{CB}$ Winter Dredge Survey does provide some data on male crabs over $127 \mathrm{~mm} \mathrm{CW}$. Based on the numbers provided by the survey, male crabs over $127 \mathrm{~mm} \mathrm{CW}$ made up $6.6 \%$ of the estimated population in 2014, 5.0\% in 2015, and 9.4\% in 2016 (Maryland Department of Natural Resources 2020). In comparison, in MCB, male crabs over $127 \mathrm{~mm} \mathrm{CW}$ made up significantly smaller proportions as only $2.4 \%$ of the total catch in 2014, $2.9 \%$ in 2015 , and $4.1 \%$ in 2016 .

The reasons for the low numbers of adult male crabs, and large crabs in general in $\mathrm{MCB}$, are speculative. One is that fishing pressure may be relatively high on this population of crabs. Currently, there is no stock assessment for blue crabs in $\mathrm{MCB}$, and no overfishing or target thresholds for catch have been determined, although commercial harvest has been relatively stable with a yearly average catch of 1.3 million pounds (Maryland Department of Natural Resources 2015). In addition, MCB have several endemic pathogens of blue crabs including Hematodinium perezi (Messick \& Shields 2000, Small et al. 2019), Parameoba perniciosa (Newman \& Ward 1973), and Callinectes ReoVirus (Johnson \& Bodammer 1975, Flowers et al. 2016). The higher prevalence of these diseases in the warmer, more saline waters of $\mathrm{MCB}$, than in $\mathrm{CB}$, may influence population structure as recruits and juveniles are more susceptible to disease and mortality (Messick \& Shields 2000, Shields 2012, Lycett et al. 2018). There is also a large decrease in the proportion of adult crabs between October and April of the following year, suggesting the possibility for overwintering mortality in larger crabs. This is supported by studies that show $H$. perezi can cause high mortality in overwintering crabs harboring the parasite (Shields et al. 2015, Huchin-Mian et al. 2018).

Molting and the growth of blue crabs are strongly affected by temperature and salinity. In the mid-Atlantic region, the period of molting and growth for blue crabs occurs from April through November (Van Engel 1958). This is based on water temperatures, as crabs cease molting below $15^{\circ} \mathrm{C}$ and begin hibernation at approximately $10^{\circ} \mathrm{C}$ (Van Engel 1958, Brylawski \& Miller 2006). Notably, the smaller MCB system, due to its size and shallow waters, warms up faster than $\mathrm{CB}$, thus leading to more active crabs earlier in the year in MCB (Hall et al. 2004). Conversely, the MCB system also cools faster in the fall for the same reasons. The subtle differences observed in size, growth, sex ratio, and maturation may be explained by these subtle differences in the physiography of MCB and $\mathrm{CB}$. MCB warm faster and cool faster, making for subtle shifts in growth rates that may be reflected as phenological shifts in crab phenotypes.

Molting appears active in the MCB system from April to November. During April sampling, which occurs mid-month, the average water temperature ranged from $14.1^{\circ} \mathrm{C}$ to $15.8^{\circ} \mathrm{C}$, depending on the year. By mid-October, when average water temperatures ranged from $17.1^{\circ} \mathrm{C}$ to $18.4^{\circ} \mathrm{C}$, molting was beginning to slow but had not ceased completely. The decrease in activity may be triggered by additional environmental conditions or seasonal cues (such as rapid decreases in water 
temperatures between September and October and diel changes in light intensity), rather than cold water temperatures alone. Tagatz (1968) found that molting slowed in blue crabs in Florida from December to February when water temperatures averaged $12.5^{\circ} \mathrm{C}$, with some crabs completely ceasing to molt for several months. In addition, most of the crabs that did not molt during winter months molted within the first 3 wk of April, when average water temperatures rose to $18.2^{\circ} \mathrm{C}$ (Tagatz 1968). Based on the current model of molting and the winter stasis period in blue crabs, once temperatures drop below a certain threshold, the molt cycle appears to reset to a "synchrony point" of late inter-molt (Smith 1997). Although crabs may hibernate in the premolt state, there are no reports to date in the literature to support this. The current understanding of molting thus suggests that crabs rapidly proceed through molting events when temperatures increase enough to end the winter stasis, which explains the high level of molting activity observed early in the year during this study.

In terms of blue crab growth, crabs may require approximately 11-12 mo of continuous growth to reach sexual maturity in CB (Van Engel 1958), compared with 7 mo in Florida (Tagatz 1968). In the mid-Atlantic region, this means that some crabs may not mature until their second year, that is, in their third season of growth. Early juvenile crabs that hatch in the early fall will then settle in mid to late fall (year 0), and overwinter as recruits (i.e., $<20 \mathrm{~mm} \mathrm{CW}$ ). These juveniles made up most of the crabs caught in April during this study (Fig. 2, Table 1). They then appear to reach $50-80 \mathrm{~mm} \mathrm{CW}$ by September of year 1 (Fig. 2), although these crabs may reach larger sizes before the winter hibernation period; however, they likely do not reach sexual maturity until the following year, reaching maturity early in year 2. This time line is supported by the large proportion of sexually mature females seen in May and June samples in this study (Table 4). In comparison, early benthic recruits that hatched early in spring (i.e., April and May) and settled in the summer appear to grow rapidly, reaching sexual maturity in the fall of their second growth season (year 1). This variation in the timing of growth to sexual maturity has been reported previously (Van Engel 1958, Hester \& Mundy 1983), but the potential impacts on growth, survival, and reproductive success are unknown and warrant closer examination.

One well-known feature of blue crab behavior in the $\mathrm{CB}$ region is the migration undertaken by recently mated females to the higher salinity waters near the mouth of the bay (Churchill 1919, Truitt 1939, Van Engel 1958, Epifanio 2019). Migration also appears to occur in other regions, such as in the Gulf of Mexico (Steele 1991). In CB, this migration typically occurs throughout the summer (Van Engel 1958, Tankersley et al. 1998). It results in large skews in sex ratio where males dominate in the low salinity sub-estuaries throughout much of the year (Hines et al. 1987), whereas females dominate in high salinity waters near the mouth of $\mathrm{CB}$ after migrating there for egglaying and hatching (Hines 2007); however, as noted by Epifanio (2019), very little is known about the migration patterns in smaller estuary systems. Whereas the pooled sex ratios calculated in this study (Table 3) look more balanced than those in $\mathrm{CB}$, variation between years, locations, and age classes suggests that this is not an accurate picture of what is occurring (Appendix Tables 1 and 2). Similar to $\mathrm{CB}$, the sub-estuaries of MCB that tend to be more fresh had sex ratios that were skewed toward male crabs (Newport Bay and St. Martin River;
Appendix Table 2). In addition, Sinepuxent Bay, which had the highest average salinity, had sex ratios skewed toward females from May to September.

These male skewed sex ratios, along with the low abundance of ovigerous females in the MCB tributaries, indicate that migration may be occurring within the MCB system, but over smaller time and distance scales as compared with CB. Importantly, Sinepuxent Bay, just south of the Ocean City Inlet, had a significantly higher proportion of sexually mature females than any other sub-estuary and also had the highest catch of ovigerous crabs, which suggests that this region is a preferred spawning ground. The high salinity in this sub-estuary also aligns with the reported physiological requirements for larval crabs (Costlow \& Bookhout 1959, Chung et al. 2012).

Early work in MCB observed that adult female crabs migrated southward into Chincoteague Bay, regardless of salinity gradients (Cargo 1958). At the time, it was believed that the primary spawning grounds were located around the Chincoteague Bay Inlet, near Wallops Island, VA, and the Ocean City Inlet had only been open for 22 y (Cargo 1958).

It is important to note that in the present study, crabs were not collected in the Virginia portion of Chincoteague Bay. The sites that were sampled in Chincoteague Bay represent the mid and upper portions of the sub-estuary and are likely more fresh than the southern portion that was not sampled. This means that the reproductive potential of this region was likely undersampled, and the Chincoteague Bay inlet is potentially a significant spawning ground for the system. In fact, ovigerous crabs were collected in the Maryland portion of Chincoteague Bay with relatively high numbers of crabs observed early in the year (April-May). No ovigerous crabs were found in other sub-estuaries in April, and very few were seen in May (Appendix Table 2). Crabs that spawn in April are likely using sperm from a mating that occurred in the previous year, which may lead to reduced brood production as sperm quantities decrease over time (Wolcott et al. 2005, Ogburn et al. 2014). Although this is only a snapshot of reproduction in the Chincoteague Bay sub-estuary, there may be important differences in reproductive timing as compared with the Sinepuxent Bay sub-estuary.

This variation in reproductive timing is reminiscent of the differences between females in upper Chesapeake and lower CB. Females in upper CB typically overwinter before reproducing because they focus on foraging and oogenesis, rather than migration (Turner et al. 2003), whereas females in the lower bay may reproduce in the same year they mate (Aguilar et al. 2005). Although the migratory patterns may differ between $\mathrm{CB}$ and MCB, the existence of two distinct spawning periods (late spring versus late summer) appears to be similar. Because the proportion of larvae that return to their home estuaries is dependent on oceanic currents and wind conditions, the time of year in which larval release occurs may play a significant role in recruitment (Epifanio 2007). In addition, the timing of recruitment may also lead to variable success as disease acquisition and subsequent mortality can be higher depending on season. For example, juvenile blue crabs were found to rapidly develop infections by Hematodinium perezi on placement in regions where the disease is prevalent and disease transmission decreased drastically because of major storm events, which are more common in the fall in the midAtlantic region (Huchin-Mian et al. 2017). This suggests that 
there may be a difference in reproductive success for these two groups, both in $\mathrm{CB}$ and MCBs.

Although there are some differences in the blue crab populations between $\mathrm{CB}$ and $\mathrm{MCB}$, there also appear to be many similarities. The variation between systems is likely due to environmental factors, such as salinity, temperature flux, depth, and habitat availability. More importantly, although the MCB system represents a smaller population, it still supports a regionally important fishery, and larvae from this system may seed other estuaries such as Chesapeake and Delaware Bay, as is suggested by gene flow in close geographical populations of blue crabs (McMillen-Jackson \& Bert 2004). Thus, the management of the MCB population will support fisheries throughout the mid-Atlantic.

\section{ACKNOWLEDGMENTS}

Funding for this research was provided by National Science Foundation CREST Award number 1036586 awarded to Dr. Paulinus Chigbu (PI). We would like to thank the Maryland Department of Natural Resources, especially Steve Doctor, Gary Tyler, Craig Weedon, and Angel Wiley.

\section{LITERATURE CITED}

Aguilar, R., A. H. Hines, T. G. Wolcott, D. L. Wolcott, M. A. Kramer \& R. N. Lipcius. 2005. The timing and route of movement and migration of post-copulatory female blue crabs, Callinectes sapidus Rathbun, from the upper Chesapeake Bay. J. Exp. Mar. Biol. Ecol. 319:117-128.

Brumbaugh, R. D. \& J. R. McConaugha. 1995. Time to metamorphosis of blue crab Callinectes sapidus megalopae: effects of benthic macroalgae. Mar. Ecol. Prog. Ser. 129:113-118.

Brylawski, B. J. \& T. J. Miller. 2006. Temperature-dependent growth of the blue crab (Callinectes sapidus): a molt process approach. Can. J. Fish. Aquat. Sci. 63:1298-1308.

Caddy, J. F., editor. 1989. Marine invertebrate fisheries their assessment and management. New York, NY: John Wiley \& Sons.

Cargo, D. G. 1958. The migration of adult female blue crabs, Callinectes sapidus Rathbun, in Chincoteague Bay and adjacent waters. J. Mar. Res. 16:180-191.

Chung, J. S. 2010. Hemolymph ecdysteroids during the last three molt cycles of the blue crab, Callinectes sapidus: quantitative and qualitative analyses and regulation. Arch. Insect Biochem. Physiol. 73:1-13.

Chung, J. S., L. Maurer, M. Bratcher, J. S. Pitula \& M. B. Ogburn. 2012. Cloning of aquaporin-1 of the blue crab, Callinectes sapidus: its expression during the larval development in hyposalinity. Aquat. Biosyst. 8:21.

Churchill, E. P. 1919. Life history of the blue crab, vol. 870. Washington, DC: Government Printing Office.

Churchill, E. P. 1942. The zoeal stages of the blue crab, Callinectes sapidus Rathbun. Solomons, MD: Chesapeake Biological Laboratory Publications, No. 49.

Costlow, J. D., Jr. \& C. G. Bookhout. 1959. The larval development of Callinectes sapidus Rathbun reared in the laboratory. Biol. Bull. 116:373-396.

Cunningham, S. R. \& M. Z. Darnell. 2015. Temperature-dependent growth and molting in early juvenile blue crabs Callinectes sapidus. J. Shellfish Res. 34:505-510.

deFur, P. L., D. Nusbaumer \& R. J. Lewis. 1988. Physiological aspects of molting in blue crabs from tidal fresh-water Potomac River, Virginia. J. Crustacean Biol. 8:12-19.

Epifanio, C. E. 2007. Biology of larvae. In: Kennedy, V. \& E. Cronin, editors. The blue crab, Callinectes sapidus. College Park, MD: Maryland Sea Grant. pp. 513-533.

Epifanio, C. E. 2019. Early life history of the blue crab Callinectes sapidus: a review. J. Shellfish Res. 38:1-22.

Fisher, M. R. 1999. Effect of temperature and salinity on size at maturity of female blue crabs. Trans. Am. Fish. Soc. 128:499-506.

Flowers, E. M., K. Simmonds, G. A. Messick, L. Sullivan \& E. J. Schott. 2016. PCR-based prevalence of a fatal reovirus of the blue crab, Callinectes sapidus (Rathbun) along the northern Atlantic coast of the USA. J. Fish Dis. 39:705-714.

Haefner, P. A. \& C. N. Shuster. 1964. Length increments during terminal molt of the female blue crab, Callinectes sapidus, in different salinity environments. Chesap. Sci. 5:114-118.
Hall, M., J. Casey \& D. Wells. 2004. A brief history of the Maryland Coastal Bays. In: Wazniak, C. E. \& M. R. Hall, editors. Maryland's coastal bays: ecosystem health assessment. Annapolis, MD: Maryland Department of Natural Resources.

Havens, K. J. \& J. R. McConaugha. 1990. Molting in the mature female blue crab, Callinectes sapidus Rathbun. Bull. Mar. Sci. 46:37-47.

Hester, B. S. \& P. R. Mundy. 1983. Impediments to rational regulation of harvest for the blue crab on Chesapeake Bay. In: Jones, P., D. Heimbuch \& C. Stagg, editors. Report of the workshop on blue crab stock dynamics in Chesapeake Bay, December 13-15, 1982. Solomons, MD: Chesapeake Biological Laboratory.

Hines, A. H. 2007. Ecology of juvenile and adult blue crabs. In: Kennedy, V. \& E. Cronin, editors. The blue crab, Callinectes sapidus. College Park, MD: Maryland Sea Grant. pp. 565-654.

Hines, A. H., R. M. Lipcius \& A. M. Haddon. 1987. Population dynamics and habitat partitioning by size, sex, and molt stage of blue crabs Callinectes sapidus in a subestuary of central Chesapeake Bay. Mar. Ecol. Prog. Ser. 36:55-64.

Huchin-Mian, J. P., H. J. Small \& J. D. Shields. 2017. Patterns in the natural transmission of the parasitic dinoflagellate Hematodinium perezi in American blue crabs, Callinectes sapidus from a highly endemic area. Mar. Biol. 164:153.

Huchin-Mian, J. P., H. J. Small \& J. D. Shields. 2018. The influence of temperature and salinity on mortality of recently recruited blue crabs, Callinectes sapidus, naturally infected with Hematodinium perezi (Dinoflagellata). J. Invertebr. Pathol. 152:8-16.

Johnson, P. T. \& J. E. Bodammer. 1975. A disease of the blue crab, Callinectes sapidus, of possible viral etiology. J. Invertebr. Pathol. 26:141-143.

Lipcius, R. N. \& W. T. Stockhausen. 2002. Concurrent decline of the spawning stock, recruitment, larval abundance, and size of the blue crab Callinectes sapidus in Chesapeake Bay. Mar. Ecol. Prog. Ser. 226:45-61.

Lipcius, R. N., W. T. Stockhausen, R. D. Seitz \& P. J. Geer. 2003. Spatial dynamics and value of a marine protected area and corridor for the blue crab in Chesapeake Bay. Bull. Mar. Sci. 72:453-469.

Lycett, K. A., J. S. Chung \& J. S. Pitula. 2018. The relationship of blue crab (Callinectes sapidus) size class and molt stage to disease acquisition and intensity of Hematodinium perezi infections. PLoS One 13:e0192237.

Maryland Department of Natural Resources. 2015. Maryland fisheries management plan report. Available at: http://dnr.maryland.gov/ fisheries/Documents/Section_10_Coastal_Bays_Blue_Crab.pdf.

Maryland Department of Natural Resources. 2020. Blue crab density tables. Available at: https://dnr.maryland.gov/fisheries/Documents/ densitytable.pdf.

Maryland Department of Natural Resources Coastal Bays Fisheries Investigation. Accessed October 5, 2020. Available at: https://dnr. maryland.gov/fisheries/Pages/coastal/investigations.aspx.

McDonald, J. H. 2014. Handbook of biological statistics, 3rd edition. Baltimore, MD: Sparky House Publishing. 
McMillen-Jackson, A. L. \& T. M. Bert. 2004. Mitochondrial DNA variation and population genetic structure of the blue crab Callinectes sapidus in the eastern United States. Mar. Biol. 145:769-777.

Messick, G. A. \& J. D. Shields. 2000. Epizootiology of the parasitic dinoflagellate Hematodinium sp. in the American blue crab Callinectes sapidus. Dis. Aquat. Org. 43:139-152.

Miller, T. J., M. J. Wilberg, A. R. Colton, G. R. Davis, A. Sharov, R. N. Lipcius, G. M. Ralph, E. G. Johnson \& A. G. Kaufman. 2011. Stock assessment of blue crab in Chesapeake Bay 2011: final assessment report. Solomons, MD: University of Maryland Center for Environmental Science.

Neufeld, D. \& J. Cameron. 1994. Mechanism of the net uptake of water in moulting blue crabs (Callinectes sapidus) acclimated to high and low salinities. J. Exp. Biol. 188:11-23.

Newman, M. W. \& G. E. Ward, Jr. 1973. An epizootic of blue crabs, Callinectes sapidus, caused by Paramoeba perniciosa. J. Invertebr. Path. 22:329-334.

NOAA (National Oceanic and Atmospheric Administration). 2018 Annual commercial landing statistics. Accessed February 5, 2018. Available at: https://www.st.nmfs.noaa.gov/commercial-fisheries commercial-landings/annual-landings-with-group-subtotals/index.

Ogburn, M. B., P. M. Roberts, K. D. Richie, E. G. Johnson \& A. H. Hines. 2014. Temporal and spatial variation in sperm stores in mature female blue crabs Callinectes sapidus and potential effects on brood production in Chesapeake Bay. Mar. Ecol. Prog. Ser. 507:249-262.

Pile, A. J., R. N. Lipcius, J. van Montfrans \& R. J. Orth. 1996. Density dependent settler recruit juvenile relationships in blue crabs. Ecol. Monogr. 66:277-300.

Porter, H. J. 1955. Variation in morphometry of the adult female blue crab, Callinectes sapidus Rathbun. M.S. thesis, Newark, DE: University of Delaware.

Porter, H. J. 1956. Delaware blue crab. Estuarine Bulletin 2:3-5.

R Core Team. 2019. R: a language and environment for statistical computing. Vienna, Austria: R Foundation for Statistical Computing. Available at: http://www.R-project.org/.

R Studio Team. 2018. RStudio: integrated development for R. Boston, MA: RStudio, Inc. Available at: http://www.rstudio.com/.

Sandoz, M. \& R. Rogers. 1944. The effect of environmental factors on hatching, moulting, and survival of zoea larvae of the blue crab Callinectes sapidus Rathbun. Ecology 25:216-228.

Shields, J. D. 2012. The impact of pathogens on exploited populations of decapod crustaceans. J. Invertebr. Path. 110:211-224.

Shields, J. D., S. E. Sullivan \& H. J. Small. 2015. Overwintering of the parasitic dinoflagellate Hematodinium perezi in dredged blue crabs (Callinectes sapidus) from Wachapreague Creek, Virginia. J. Invertebr. Path. 130:124-132.

Small, H. J., J. P. Huchin-Mian, K. S. Reece, K. P. Lohan, M. J. Butler, IV \& J. D. Shields. 2019. Parasitic dinoflagellate Hematodinium perezi prevalence in larval and juvenile blue crabs Callinectes sapidus from coastal bays of Virginia. Dis. Aquat. Org. 134:215-222.
Smith, S. G. 1997. Models of crustacean growth dynamics. PhD diss., College Park, MD: University of Maryland College Park.

Smith, M. T. \& J. T. Addison. 2003. Methods for stock assessment of crustacean fisheries. Fish. Res. 65:231-256.

Smith, S. G. \& E. S. Chang. 2007. Molting and growth. In: Kennedy, V. \& E. Cronin, editors. The blue crab, Callinectes sapidus. College Park, MD: Maryland Sea Grant. pp. 197-254.

Söderhäll, K. \& V. J. Smith. 1983. Separation of the haemocyte populations of Carcinus maenas and other marine decapods, and prophenoloxidase distribution. Dev. Comp. Immunol. 7:229-239.

Soumoff, C. \& D. M. Skinner. 1983. Ecdysteroid titers during the molt cycle of the blue crab resemble those of other Crustacea. Biol. Bull. 165:321-329.

Steele, P. 1991. Population dynamics and migration of the blue crab, Callinectes sapidus (Rathbun), in the eastern Gulf of Mexico. Proc. Gulf Caribb. Fish. Inst. 40:241-244.

Tagatz, M. E. 1968. Growth of juvenile blue crabs, Callinectes sapidus Rathbun, in the St. Johns River, Florida. Fish Bull. 67:281-288. (Wash D C).

Tankersley, R. A., M. G. Wieber, M. A. Sigala \& K. A. Kachurak. 1998. Migratory behavior of ovigerous blue crabs Callinectes sapidus: evidence for selective tidal-stream transport. Biol. Bull. 195:168-173.

Techa, S. \& J. S. Chung. 2013. Ecdysone and retinoid-X receptors of the blue crab, Callinectes sapidus: cloning and their expression patterns in eyestalks and Y-organs during the molt cycle. Gene 527:139-153.

Torrejon-Magallanes, J. 2020. sizeMat: estimate size at sexual maturity. $\mathrm{R}$ package version 1.1.2. Available at: https://CRAN.R-project.org/ package $=$ sizeMat.

Truitt, R. V. 1939. The blue crab. In: Our water resources and their conservation. Solomons Island, MD: University of Maryland, Chesapeake Biological Laboratory, Contribution 27.

Turner, H. V., D. L. Wolcott, T. G. Wolcott \& A. H. Hines. 2003. Postmating behavior, intramolt growth, and onset of migration to Chesapeake Bay spawning grounds by adult female blue crabs, Callinectes sapidus Rathbun. J. Exp. Mar. Biol. Ecol. 295:107-130.

Van Engel, W. A. 1958. The blue crab and its fishery in Chesapeake Bay. Part 1. Reproduction, early development, growth and migration. Commer. Fish. Rev., 20:6-17.

Van Engel, W. A. 1990. Development of the reproductively functional form in the male blue crab, Callinectes sapidus. Bull. Mar. Sci. 46:13-22.

Williams, A. B. 1984. Shrimps, lobsters, and crabs of the Atlantic coast of the eastern United States, Maine to Florida. Washington, DC: Smithsonian Institution Press.

Wolcott, D. L., C. W. B. Hopkins \& T. G. Wolcott. 2005. Early events in seminal fluid and sperm storage in female blue crab Callinectes sapidus Rathbun: effects of male mating history, male size, and season. J. Exp. Mar. Biol. Ecol. 319:43-55.

Zmora, O., A. Findiesen, J. Stubblefield, V. Frenkel \& Y. Zohar. 2005. Large-scale juvenile production of the blue crab Callinectes sapidus. Aquaculture 244:129-139. 
Population Structure of Blue Crabs

2014
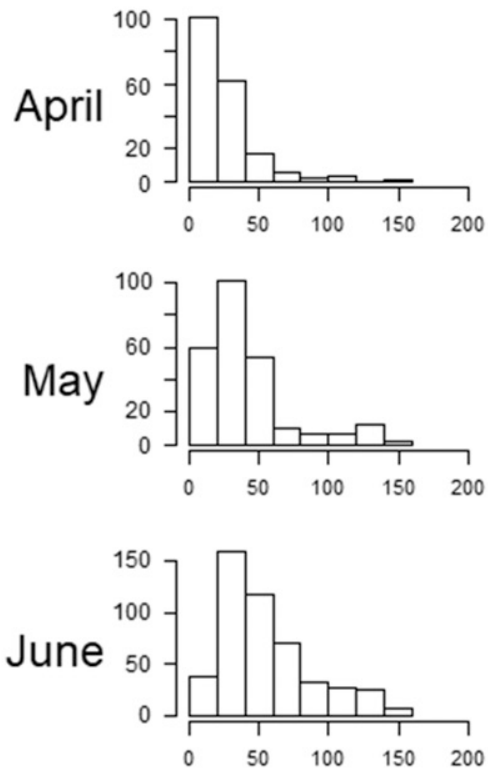

함
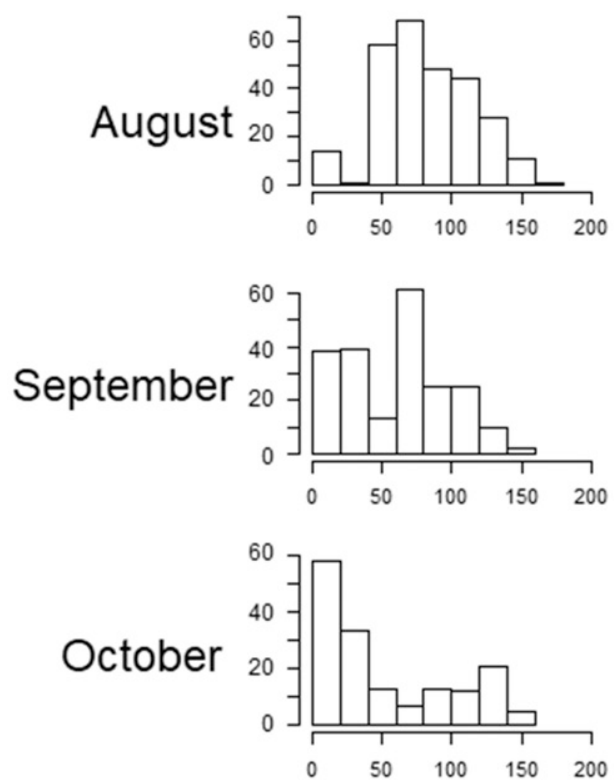

2015
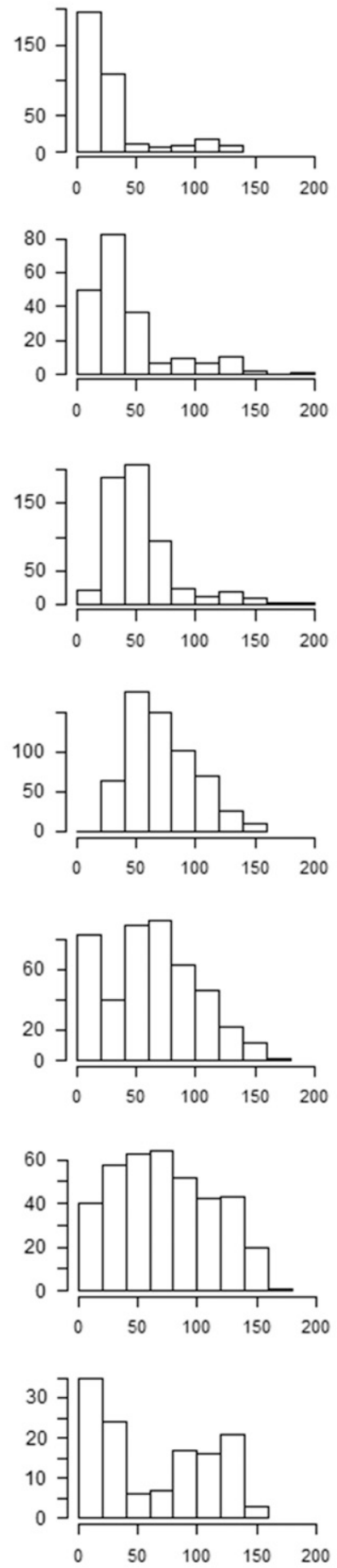

2016
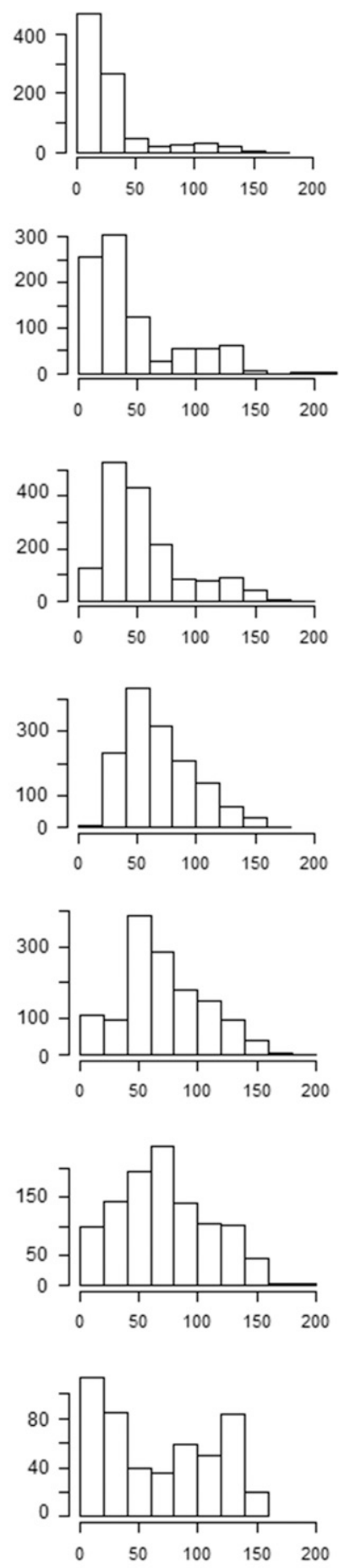

\section{Carapace Width $(\mathrm{mm})$}

Appendix Figure 1. Size frequency histograms by month and year for crab carapace width. 
APPENDIX TABLE 1.

Sex ratios by month unpooled.

\begin{tabular}{|c|c|c|c|c|c|c|c|c|}
\hline 2014 & April & May & June & July & August & September & October & Total \\
\hline Female & 75 & 131 & 250 & 213 & 143 & 92 & 64 & 968 \\
\hline Male & 115 & 122 & 255 & 224 & 130 & 124 & 89 & 1,059 \\
\hline$X^{2}$ & 8.42 & 0.32 & 0.05 & 0.27 & 0.62 & 4.72 & 4.09 & 4.10 \\
\hline$P$-value & $3.7 \times 10^{-3}$ & 0.57 & 0.82 & 0.60 & 0.43 & 0.029 & 0.043 & 0.043 \\
\hline 2015 & April & May & June & July & August & September & October & Total \\
\hline Female & 149 & 77 & 284 & 297 & 176 & 136 & 38 & 1,157 \\
\hline Male & 203 & 127 & 293 & 306 & 270 & 246 & 91 & 1,536 \\
\hline$X^{2}$ & 8.28 & 12.3 & 0.14 & 0.13 & 19.80 & 31.70 & 21.80 & 53.30 \\
\hline$P$-value & $4.0 \times 10^{-3}$ & $4.6 \times 10^{-4}$ & 0.71 & 0.71 & $8.6 \times 10^{-6}$ & $1.8 \times 10^{-3}$ & $3.1 \times 10^{-6}$ & $2.8 \times 10^{-3}$ \\
\hline 2016 & April & May & June & July & August & September & October & Total \\
\hline Female & 133 & 198 & 238 & 191 & 344 & 208 & 83 & 1,395 \\
\hline Male & 204 & 230 & 267 & 193 & 286 & 266 & 113 & 1,559 \\
\hline$X^{2}$ & 15.0 & 2.39 & 1.67 & 0.01 & 5.34 & 7.10 & 4.59 & 9.10 \\
\hline$P$-value & $1.1 \times 10^{-4}$ & 0.12 & 0.20 & 0.92 & 0.021 & $7.7 \times 10^{-3}$ & 0.032 & $2.5 \times 10^{-3}$ \\
\hline Mature & April & May & June & July & August & September & October & Total \\
\hline Female & 9 & 27 & 83 & 61 & 93 & 91 & 45 & 409 \\
\hline Male & 27 & 67 & 90 & 114 & 109 & 121 & 85 & 613 \\
\hline$X^{2}$ & 3.79 & 8.04 & 0.07 & 7.61 & 0.49 & 1.86 & 5.69 & 20.16 \\
\hline$P$-value & 0.051 & $4.6 \times 10^{-3}$ & 0.79 & $5.8 \times 10^{-3}$ & 0.49 & 0.17 & 0.017 & $7.1 \times 10^{-6}$ \\
\hline
\end{tabular}

The "Mature" group contains only sexually mature females and males in the adult category. Because of relatively small sample sizes, these data are pooled across all $3 \mathrm{y}$. 
APPENDIX TABLE 2.

Monthly sex ratios, female maturity and condition, and salinity by subestuary.

\begin{tabular}{|c|c|c|c|c|c|c|c|c|}
\hline Assawoman & April & May & June & July & August & September & October & Total \\
\hline Female & 29 & 48 & 123 & 124 & 153 & 92 & 53 & 622 \\
\hline Male & 41 & 69 & 114 & 80 & 149 & 117 & 62 & 632 \\
\hline Total & 70 & 117 & 237 & 204 & 302 & 209 & 115 & 1,254 \\
\hline$\%$ Female & $41.4 \%$ & $41.0 \%$ & $51.9 \%$ & $60.8 \%$ & $50.7 \%$ & $44.0 \%$ & $46.1 \%$ & $49.6 \%$ \\
\hline$\%$ Mature Females & $0.0 \%$ & $16.7 \%$ & $7.3 \%$ & $11.3 \%$ & $16.3 \%$ & $19.6 \%$ & $17.0 \%$ & $13.3 \%$ \\
\hline Ovigerous & 0 & 1 & 6 & 8 & 4 & 1 & 0 & 20 \\
\hline Avg. Salinity & 25.1 & 24.3 & 24.9 & 27.5 & 26.7 & 28.7 & 25.3 & 26.1 \\
\hline
\end{tabular}

\begin{tabular}{lcccccccc}
\hline \multicolumn{1}{c}{ Chincoteague } & April & May & June & July & August & September & October & Total \\
\hline Female & 179 & 154 & 296 & 234 & 206 & 125 & 79 & 1,273 \\
Male & 256 & 150 & 290 & 232 & 171 & 131 & 99 & 1,329 \\
Total & 435 & 304 & 586 & 466 & 377 & 256 & 178 & 2,602 \\
\% Female & $41.1 \%$ & $50.7 \%$ & $50.5 \%$ & $50.2 \%$ & $54.6 \%$ & $48.8 \%$ & $44.4 \%$ & $48.9 \%$ \\
\% Mature Females & $5.0 \%$ & $6.5 \%$ & $7.8 \%$ & $3.8 \%$ & $9.2 \%$ & $23.8 \%$ & $32.9 \%$ & $9.8 \%$ \\
Ovigerous & 6 & 6 & 2 & 1 & 0 & 0 & 0 & 15 \\
Avg. Salinity & 26.3 & 24.3 & 27.5 & 29 & 30 & 30.8 & 27.4 & 27.9 \\
& & Average size of sexually mature females $=130.0 \mathrm{~mm} \mathrm{CW}$ & &
\end{tabular}

\begin{tabular}{lcccccccc}
\hline \multicolumn{1}{c}{ Isle of Wight } & April & May & June & July & August & September & October & Total \\
\hline Female & 65 & 61 & 93 & 134 & 100 & 72 & 15 & 540 \\
Male & 70 & 75 & 83 & 96 & 74 & 95 & 28 & 521 \\
Total & 135 & 136 & 176 & 230 & 174 & 167 & 43 & 1,061 \\
\% Female & $48.1 \%$ & $44.9 \%$ & $52.8 \%$ & $58.3 \%$ & $57.5 \%$ & $43.1 \%$ & $34.9 \%$ & $50.9 \%$ \\
\% Mature Females & $0.0 \%$ & $1.6 \%$ & $5.4 \%$ & $9.7 \%$ & $19.0 \%$ & $22.2 \%$ & $26.7 \%$ & $10.7 \%$ \\
Ovigerous & 0 & 0 & 3 & 8 & 6 & 0 & 0 & 17 \\
Avg. Salinity & 21.8 & 24.8 & 27.5 & 27.9 & 28 & 28.9 & 26.4 & 26.8 \\
& & Average size of sexually mature females $=135.4 \mathrm{~mm} \mathrm{CW}$ & &
\end{tabular}

\begin{tabular}{lcccccccc}
\hline \multicolumn{1}{c}{ Sinepuxent } & April & May & June & July & August & September & October & Total \\
\hline Female & 8 & 6 & 105 & 48 & 39 & 29 & 5 & 240 \\
Male & 9 & 5 & 51 & 41 & 22 & 16 & 9 & 153 \\
Total & 17 & 11 & 156 & 89 & 61 & 45 & 14 \\
\% Female & $47.1 \%$ & $54.5 \%$ & $67.3 \%$ & $53.9 \%$ & $63.9 \%$ & $64.4 \%$ & $35.7 \%$ & $61.1 \%$ \\
\% Mature Females & $12.5 \%$ & $33.3 \%$ & $39.4 \%$ & $35.4 \%$ & $41.0 \%$ & $37.9 \%$ & $20.0 \%$ & $37.2 \%$ \\
Ovigerous & 0 & 1 & 25 & 5 & 7 & 2 & 0 & 40 \\
Avg. Salinity & 29.7 & 27.3 & 28.8 & 28.8 & 29.3 & 30.3 & 28.3 & 29.1 \\
& & Average size of sexually mature females $=132.7 \mathrm{~mm} \mathrm{CW}$ & &
\end{tabular}

\begin{tabular}{|c|c|c|c|c|c|c|c|c|}
\hline Newport & April & May & June & July & August & September & October & Total \\
\hline Female & 18 & 32 & 67 & 61 & 64 & 35 & 16 & 293 \\
\hline Male & 71 & 66 & 128 & 130 & 123 & 122 & 59 & 699 \\
\hline Total & 89 & 98 & 195 & 191 & 187 & 157 & 75 & 992 \\
\hline$\%$ Female & $20.2 \%$ & $32.7 \%$ & $34.4 \%$ & $31.9 \%$ & $34.2 \%$ & $22.3 \%$ & $21.3 \%$ & $29.5 \%$ \\
\hline$\%$ Mature Females & $0.0 \%$ & $18.8 \%$ & $1.6 \%$ & $1.6 \%$ & $12.5 \%$ & $31.4 \%$ & $18.8 \%$ & $10.4 \%$ \\
\hline Ovigerous & 0 & 1 & 0 & 0 & 0 & 0 & 0 & 1 \\
\hline Avg. Salinity & 23.9 & 23.8 & 24.6 & 24.9 & 25.8 & 27.4 & 25 & 25.1 \\
\hline \multicolumn{9}{|c|}{ Average size of sexually mature females $=135.6 \mathrm{~mm} \mathrm{CW}$} \\
\hline St. Martin River & April & May & June & July & August & September & October & Total \\
\hline Female & 59 & 105 & 88 & 100 & 101 & 83 & 17 & 553 \\
\hline Male & 75 & 114 & 149 & 144 & 147 & 155 & 36 & 820 \\
\hline Total & 134 & 219 & 237 & 244 & 248 & 238 & 53 & 1,373 \\
\hline$\%$ Female & $44.0 \%$ & $47.9 \%$ & $37.1 \%$ & $41.0 \%$ & $40.7 \%$ & $34.9 \%$ & $32.1 \%$ & $40.3 \%$ \\
\hline$\%$ Mature Females & $0.0 \%$ & $0.0 \%$ & $4.5 \%$ & $7.0 \%$ & $6.9 \%$ & $6.0 \%$ & $11.8 \%$ & $4.5 \%$ \\
\hline Ovigerous & 0 & 0 & 0 & 2 & 0 & 0 & 0 & 2 \\
\hline Avg. Salinity & 22.6 & 21.8 & 24.5 & 26 & 24.5 & 27.2 & 24.6 & 24.6 \\
\hline \multicolumn{9}{|c|}{ Average size of sexually mature females $=138.1 \mathrm{~mm} \mathrm{CW}$} \\
\hline
\end{tabular}

$\mathrm{CW}$, carapace width. Salinity is calculated as the average of all data points of bottom salinity recorded at each site within the subestuary. A list of the subestuaries, and the respective sites in each subestuary, is provided in Figure 1. 
APPENDIX TABLE 3.

Salinity (ppt) for individual sites 2014-2016.

\begin{tabular}{|c|c|c|c|c|c|c|c|c|c|c|}
\hline 2014 & T001 & T002 & T003 & T004 & T005 & T006 & T007 & T008 & T009 & T010 \\
\hline April & 13.6 & 14.3 & 12.4 & 13.7 & 16.4 & 17.1 & - & - & - & 12.3 \\
\hline May & 21.1 & 21.1 & - & 22.2 & 23.5 & 23.1 & 16.9 & - & 18.9 & 21.2 \\
\hline June & 24.8 & 25 & 24.5 & 24.4 & 26.5 & 25.2 & 25.3 & 26.1 & 28 & 27.1 \\
\hline July & 27.1 & 27 & 26.5 & 27.3 & 28.9 & 28.7 & 21.9 & 26.7 & 26.9 & 27.1 \\
\hline August & 25.2 & 25.3 & 25.2 & 25.3 & 26.3 & 25.6 & 23.7 & 23.9 & 24.2 & 26.2 \\
\hline September & 23.5 & 23.5 & - & 24.4 & 24.8 & 25.3 & 22.3 & - & 23.3 & 23.5 \\
\hline October & 18.3 & 18.6 & 18.3 & 19 & 19.9 & 20.1 & 18.6 & - & - & - \\
\hline Average & 21.94 & 22.11 & 21.38 & 22.33 & 23.76 & 23.59 & 21.45 & 25.57 & 24.26 & 22.90 \\
\hline 2015 & T001 & T002 & T003 & T004 & T005 & T006 & T007 & T008 & T009 & T010 \\
\hline April & 14.2 & 14.5 & - & 13.7 & 16.2 & 16.2 & - & - & - & - \\
\hline May & 23.3 & 23.3 & 22.5 & 23.9 & 25.7 & 26.4 & - & - & 13.9 & 20.3 \\
\hline June & 26 & 26.6 & 23.9 & 26 & 28.6 & 28.3 & 23.8 & 21 & 23.1 & 28.3 \\
\hline July & 27.8 & 27.7 & 27.1 & 27.7 & 28.7 & 29.2 & 26.9 & 22.3 & 22.4 & 27.4 \\
\hline August & 27.4 & 27.7 & 27.3 & 28.2 & 29.9 & 29.6 & 27.1 & 23.2 & 23.4 & 25.4 \\
\hline September & 24.4 & 24.6 & 23.8 & 27.2 & 28 & 28.4 & 23.5 & 23.8 & 22.9 & 26.2 \\
\hline October & 18.8 & 19 & 18.7 & 19.1 & 13.1 & 12.4 & 18.9 & - & 14.8 & 12.4 \\
\hline Average & 23.13 & 23.34 & 23.88 & 23.69 & 24.31 & 24.36 & 24.04 & 22.58 & 20.08 & 23.33 \\
\hline 2016 & T001 & T002 & T003 & T004 & T005 & T006 & T007 & T008 & T009 & T010 \\
\hline April & 16.6 & 15.4 & 14.8 & 12.4 & 14.1 & 13.6 & - & - & 12.3 & 14.6 \\
\hline May & 16 & 16.3 & 15.8 & 16.5 & 18.3 & 18.2 & 16.5 & - & - & - \\
\hline June & 24.8 & 25.5 & 24.2 & 23.8 & 25.2 & 25 & 22 & 20.2 & 25 & 23 \\
\hline July & 27.3 & 27.3 & 27.1 & 28.4 & 29.1 & 31.2 & 27.2 & - & 24.3 & 28.1 \\
\hline August & 30.2 & 30.2 & 30.1 & 32.3 & 31.9 & 30.8 & 29.3 & 20.8 & 23 & 28.9 \\
\hline September & 23.8 & 23 & 23.5 & 25.8 & 25.9 & 25.9 & 24.8 & 23.6 & 23.4 & 24.9 \\
\hline October & 18.3 & 18.6 & 18.7 & 18.8 & 20.2 & 19.6 & - & - & 17.6 & 16.6 \\
\hline Average & 22.43 & 22.33 & 22.03 & 22.57 & 23.53 & 23.47 & 23.96 & 21.53 & 20.93 & 22.68 \\
\hline 2014 & T011 & T012 & T013 & T014 & T015 & T016 & T017 & T018 & T019 & T020 \\
\hline April & 13.2 & 13.4 & 13.2 & 14.1 & 14.4 & 13.8 & - & 15 & 15.3 & - \\
\hline May & - & 21.7 & 20.3 & 21 & 20.3 & 22.4 & 23 & 23.3 & 23.8 & 22.8 \\
\hline June & 25.6 & 26.2 & 24.8 & 25.4 & 24.2 & 27 & 25.8 & 26.6 & 27 & 26.8 \\
\hline July & 27 & 26.5 & 26.8 & 27.1 & 26.5 & 26.5 & 25.7 & 25.5 & 26.2 & 26.2 \\
\hline August & 26.3 & 25.9 & 25.9 & 25.9 & 26.8 & 26.6 & 26.6 & 26.9 & 26.6 & 26.7 \\
\hline September & 22.3 & 21.5 & 21.5 & 22.5 & 22.1 & - & 22.6 & 22.3 & 22.4 & 22.7 \\
\hline October & 14.2 & 13.5 & 14.3 & 14.2 & 20.7 & 20.5 & 20.5 & 21.1 & 21.3 & 20.7 \\
\hline Average & 21.43 & 21.24 & 20.97 & 21.46 & 22.14 & 22.80 & 24.03 & 22.96 & 23.23 & 24.32 \\
\hline 2015 & T011 & T012 & T013 & T014 & T015 & T016 & T017 & T018 & T019 & T020 \\
\hline April & 14 & 15 & 13.6 & 13.9 & 17.5 & 17.5 & 17.4 & 17.6 & 18.1 & 17.8 \\
\hline May & 20.3 & 20.7 & 20.9 & 24.2 & 25.1 & 23.9 & 23.9 & 24.8 & 24.9 & 23.7 \\
\hline June & 27.8 & 28.6 & 27.3 & 28.6 & 28.4 & 24.1 & 23.6 & 25.3 & 26.1 & 23.7 \\
\hline July & 26.6 & 26.2 & 26.4 & 26.6 & 26.4 & 28.3 & 27.1 & 27.8 & 28.8 & 27.8 \\
\hline August & 26.1 & 26.5 & 25.2 & 24.7 & 25.7 & 25.2 & 25 & 25.1 & 25.7 & 25.1 \\
\hline September & 26.2 & 25.8 & 26.4 & 21.3 & 22.5 & 24.2 & 23.4 & 24.6 & 24.8 & 24 \\
\hline October & 13.1 & 10.5 & 19 & 19 & 18.9 & 19.2 & 19 & 19.5 & 19.6 & 19.3 \\
\hline Average & 22.01 & 21.90 & 22.69 & 22.61 & 23.50 & 23.20 & 22.77 & 23.53 & 24.00 & 23.06 \\
\hline 2016 & T011 & T012 & T013 & T014 & T015 & T016 & T017 & T018 & T019 & T020 \\
\hline April & 15.4 & 17.1 & 15.6 & 15.5 & 14.4 & 15.7 & 15.2 & 15.2 & 15 & 16 \\
\hline May & 17.5 & 18.4 & 16.9 & 16.9 & 17.9 & 17.9 & 17.9 & 19.7 & 19.9 & 18.1 \\
\hline June & 23.2 & 23.3 & 23.4 & 26.3 & 25.9 & 25 & 24.1 & 24.8 & 25 & 24.9 \\
\hline July & 28.4 & 29.2 & 28.5 & 28.5 & 27.4 & 29 & 29.1 & 29.4 & 29.9 & 29.1 \\
\hline August & 30.6 & 31.2 & 30.3 & 29.8 & 29.4 & 27 & 26.3 & 26.6 & 26.8 & 27.3 \\
\hline September & 24.1 & 23.9 & 22.3 & 22.4 & 21.7 & 22.6 & 23.99 & 23.87 & 23.59 & 23.95 \\
\hline October & 17.2 & 16 & 15.8 & 15.8 & 14.4 & 17.2 & 17.2 & 17.5 & 17.6 & 17.4 \\
\hline Average & 22.34 & 22.73 & 21.83 & 22.17 & 21.59 & 22.06 & 21.97 & 22.44 & 22.54 & 22.39 \\
\hline
\end{tabular}

Sites where no crabs were collected are not included in the dataset used in this study. For these sites, no environmental data is available and they are denoted by - in the table. 
APPENDIX TABLE 4.

Ovigerous crab catch out of total mature female catch by month.

\begin{tabular}{|c|c|c|c|c|c|c|c|c|}
\hline Year & April & May & June & July & August & September & October & Total ovigerous \\
\hline 2014 & $0 / 0$ & $2 / 3$ & $5 / 24$ & $10 / 30$ & $2 / 24$ & $0 / 6$ & $0 / 8$ & 19 \\
\hline 2015 & $0 / 0$ & $0 / 2$ & $2 / 12$ & $8 / 20$ & $2 / 24$ & $1 / 44$ & $0 / 13$ & 13 \\
\hline 2016 & $6 / 9$ & $7 / 22$ & $29 / 47$ & $6 / 11$ & $13 / 45$ & $2 / 41$ & $0 / 24$ & 63 \\
\hline Total ovigerous & 6 & 9 & 36 & 24 & 17 & 3 & - & 95 \\
\hline
\end{tabular}

